\title{
Political Corruption and White-Collar Crime Related to Covid-19 Countermeasures
}

\author{
Safaana Salwa Salsabila \\ International Relations Department \\ University of Lampung \\ Lampung, Indonesia \\ Safaana.salwa1022@students.unila.ac.id
}

\author{
Khairunnisa Simbolon \\ International Relations Department \\ University of Lampung \\ Lampung, Indonesia \\ khairunnisa.simbolon@ fisip.unila.ac.id
}

\author{
Iwan Sulistyo* \\ International Relations Department \\ University of Lampung \\ Lampung, Indonesia \\ iwan.sulistyo@fisip.unila.ac.id \\ Syamsul Ma'arif \\ Public Administration Department \\ University of Lampung \\ Lampung, Indonesia \\ syamsul.maarif@fisip.unila.ac.id
}

\author{
Hasbi Sidik \\ International Relations Department \\ University of Lampung \\ Lampung, Indonesia \\ hasbi.sidik@fisip.unila.ac.id
}

\begin{abstract}
From the beginning of 2020, the emergence and spread of Covid-19 has very astonishing implications for almost the entire world population. During increasingly complicated global conditions, there is a tremendous need to respond. However, it turned out that there were acts of abuse of authority by government officials. Using a research strategy through archive studies, mainly numerous news from the internet, the data were analyzed with content analysis. This qualitative-descriptive research examines forms of political corruption and patterns of White-Collar Crime (WCC) related to handling the Covid-19 pandemic carried out by government officials in several countries in the world, including Indonesia. This study finds two forms of political corruption, namely those committed by government employees and corporations. This study also shows that the educational backgrounds of the perpetrators are relatively good, and the actors take advantage of high-end networks in carrying out their actions. The impact of the crime in the context of handling the pandemic in several countries is threatening people's lives in the broadest spectrum.
\end{abstract}

Keywords: Political Corruption, White-Collar Crime, Covid-19

\section{INTRODUCTION}

In terms of its chronological emergence, 'Covid19 ' began with an announcement delivered by the World Health Organization (WHO) on December 31, 2019, stating that Wuhan Municipal Health Commission found clusters of pneumonia cases in Wuhan, Hubei Province, China [1]. Announcements by $\mathrm{WHO}$ and reporting by various international mass media had intensively continued since January 2020 until this research outline was designed.
Concerning the number of cases, data published in real-time and updated continuously can, of course, be referred to the dashboard page of WHO, an agency under the United Nations (UN) which is indeed mandated to deal with the world health problem, including Covid-19. The authors have captured a graph of the development of the spread of Covid-19 cases from the beginning of its appearance until Monday, March 1, 2021, at 12:07 Jakarta time (see Graphic 1). It is clear that globally confirmed cases have reached $113,467,303$ people, with 2,520,550 died. By and large, since the beginning of the spread of Covid-19, the graph has been steadily climbing, both for the number of confirmed cases as well as the number of fatalities.

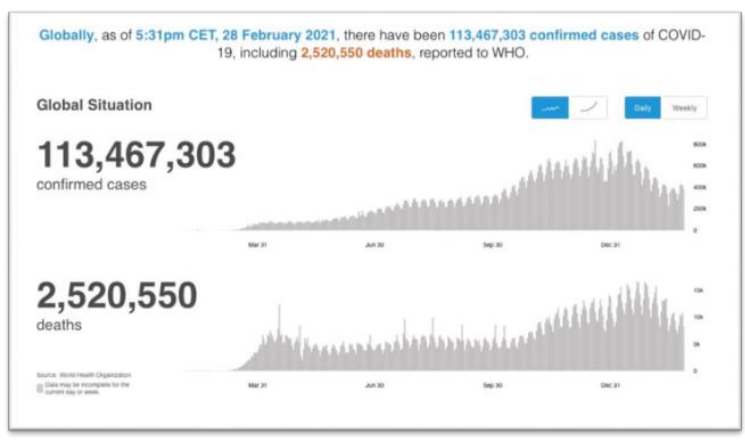

Fig. 1. Number of Cases of Covid-19 [2].

Social facts that have been and are always recorded through updating the number of cases and fatalities will always be in line with changes in the life of the world community, which cannot be dammed/avoided by all groups, from the lower class to the upper class (with high socioeconomic status). For example, the policy of Working from Home 
(WFH), meetings that are now held online (online, online), restrictions on gatherings in public areas, social distancing, and washing hands, and so on.

In the context of efforts to contain the spread of Covid-19, unfortunately, it turns out that there have been acts of abuse of authority by government officials, policymakers, and bureaucracies in several countries in the world. For the time being, their actions are suspected to be to enrich themselves or their immediate circle. By using the English keyword "corruption covid-19" through a search on the Google.com page, the authors of this proposal have captured several cases, namely in Indonesia, where there is suspected involvement of high-ranking officials in the social ministry [3]; in Vietnam, allegedly involving officials at its Hanoi's Center for Disease Control [4]; and in Africa, among others: Mozambique, Zimbabwe, South Africa, and Madagascar [5]. A series of corruption cases about the handling of the Covid-19 outbreak, over time, is likely to continue to occur. Therefore, these researchers (proposal writers) consider it essential and crucial to examine a number of these cases from the point of view of Political Corruption and WhiteCollar Crime, so that it is hoped that a mechanism for handling and enforcing the law can be formulated which ultimately relates to improvements in governance. Manage the bureaucracy.

\section{THEORETICAL FRAMEWORK}

\section{A. Political Corruption}

Before explaining the term political corruption, it is necessary to state the definition of corruption. So many and broad definitions of corruption are available in various literature. However, it is better if we quote the meaning of corruption from an institution that consistently and credible focuses on corruption issues, namely Transparency International (TI). It means corruption as:

"the abuse of entrusted power for private gain. [It] erodes trust, weakens democracy, hampers economic development and further exacerbates inequality, poverty, social division and the environmental crisis. Exposing corruption and holding the corrupt to account can only happen if we understand the way corruption works and the systems that enable it." [6].

In other words, corruption is very destructive and detrimental to life and requires firm handling based on a complete understanding of how corruption works. Furthermore, TI describes that corruption can occur in various forms with the following behavioral scopes:

- civil servants who demand or receive money or favors in exchange for services;

- politicians misappropriating public money or awarding public jobs or contracts to their sponsors, friends and family;
- the company bribes officials to get a lucrative deal. [7].

In order to be more clearly manifested, in this study, political corruption related to the handling of the Covid-19 pandemic will be focused on its various forms. The variant refers to the writings of Andvig, Fjeldstad Inge Amundsen, Sissener, \& Søreide [8], namely: bribery, fraud, extortion, and favoritism. In this research, attention will be focused on the causes and impacts/consequences of political corruption carried out about the handling of the Covid-19 pandemic [9].

\section{B. White Collar Crimes}

There is one key phrase that is relatively appropriate to be used by anyone who is trying to understand what has happened in the last few days (and seems always to be preached), namely 'white-collar crime' (WCC) - a crime by the upper class or those whom high socioeconomic status related to their work. The perpetrators are called 'white-collar criminals'. The early thinker who introduced this concept to the academic community, namely Edwin Hardin Sutherland. He presented his 1939 presentation before the American Sociological Association and, about ten years later, Sutherland published his work, WhiteCollar Crime [10]. In his work, Sutherland wrote the definition of WCC as "a crime committed by a person of respectability and high social status in the course of his occupation” [11]

In the study of white-collar crime, there are several typologies proposed by several criminologists. Among them namely Marshall B. Clinard and Richard Quinney, who divide white-collar crime into two types: occupational crime (law violations committed by a person in connection with his work for personal gain) and corporate crime (law violations committed by company officials). for the benefit of the company) [9]. John F. Conklin divides white-collar crime into three types, namely:

- Corporate crimes, such as misleading advertising, tax evasion, environmental pollution by factories, and so on.

- Crimes committed by company employees, such as embezzlement of money, theft by employees and so on.

- Crimes committed by government employees, such as police brutality, accepting bribes, embezzlement of money, embezzlement of state money and so on. [12].

\section{RESEARCH METHODS}

This study uses a qualitative descriptive. As suggested by Payne [10], we use a case studies research strategy by also relying on archival research, not surveys, field research, or experiments. The selection of the research strategy was based on the consideration that the last four strategies would 
require a large amount of budget and human resources. Realizing this, researchers will filter or search through the internet.

Data retrieval is carried out through library research through internet searches. The type of data used is qualitative, with secondary data. Data were obtained mainly from credible online news sites, Transparency International (TI, https://www.transparency.org/en), The World Health Organization (WHO, https://www.who.int), the United Nations Office on Drugs and Crime (UNODC,

https://www.unodc.org/unodc/index.html), The World

Bank

(https://databank.worldbank.org/databases/control-

of-corruption), and - how. The data referred to are related to physical losses, socioeconomic losses, and emotional consequences caused by corrupt practices by actors with good social status who serve in the Government in the context of handling Covid-19; also related to the pattern of cooperation of the actors involved, as well as the roles they play. The data analysis technique that will be used, as has been done by Mustofa [13], is content analysis (content analysis) from mass media coverage on the internet and from some credible institutions that provide data related to corruption.

\section{RESULTS AND DISCUSSIONS}

\section{A. Forms Of Political Corruption Crimes During The Covid-19 Pandemic In Various Countries}

At the beginning of the pandemic, we can see the actions of individuals who try to take advantage by hoarding goods and resulting in the loss of items that are very important to overcome the pandemic, such as masks, hand sanitizers, medical alcohol, and medicines. As a result of this effort, the prices of these goods soared and made it difficult for people already affected by the pandemic. This is still a small scale and the losses incurred are not as big as the crimes committed by perpetrators of political corruption and white-collar crimes.

Research from Devex traces from January 1, 2020, to January 31, 2021, more than US\$ 21.7 billion has been disbursed worldwide to fight the spread of this virus [14]. These funds come from a wide variety of charities, global aid, international debt, and grants. With the demand for a quick response, a large number of funds loosened checks and balances triggered the emergence of corruption by public officials and whitecollar people. The loss is no longer at the level of hoarders but the state level.

A notification by Red Palta exposes, that in any case, 13 states in Latin America are transforming their regulations for buying a Covid-19 vaccine easier. It announced that 23 laws, decrees, and resolutions weakening transparent measures in public contracts. These also lead the public immunity to certain pharmaceutical corporations in bearing Covid-19 vaccines. Interestingly, the tendency of political corruption carried out by white collars in the health sector during this pandemic occurs in both developing and developed countries (in the case of Britain, the United States, and Italy, for example).

Transparency International also finds that, in April 2021 , it is possibly one in five British governmental contracts linking to the measures in countering pandemic is associated with corruptive actions. The government itself had five bilateral agreements to 270 million doses of vaccine for saving 66 million citizens. A report reveals that 24 PPE contracts, totaling $£ 1$.6bn, were given to those who have a political link to the Conservative Party, including three contracts of $£ 536 \mathrm{~m}$ to politically related firms for Covid-19 testing services [7].

The success of lab tests on vaccines which is the hope for the creation of herd immunity, will also bring new fertile fields for white-collar criminals. The high demand for vaccines, which is not accompanied by production capacity, has made vaccines a "conquest" for countries. Private pharmaceutical companies provide unfair clauses, and this process will limit the early detection of corruption between unscrupulous government officials and suppliers (pharmacies). Other possible frauds are procurement, price injustice, and monopolies [15]. We can see the difference in the price of the Sinovac vaccine in Southeast Asian countries [16] and vaccine standard fraud that occurs in Latin American countries. Vaccine companies with bribery records, such as Sinovac Biotech, have price confidentiality clauses and can decide how much they sell for different countries with a confidential procedure. Regarding the Covid-19 vaccine's acquisition and present to the public, nongovernmental penetration could be a hazardous opportunity for committing corruption. in this context, Pakistan is considered the first state to make import and commercialization possible [17]. The following is the price of the covid-19 vaccine:

TABLE I. TABLE 1. Covid-19's VACCINE PRICE

\begin{tabular}{|l|l|l|}
\hline \multicolumn{1}{|c|}{ Developer } & \multicolumn{1}{|c|}{$\begin{array}{c}\text { Name of } \\
\text { Vaccines/Prototype }\end{array}$} & $\begin{array}{c}\text { Estimated } \\
\text { Price } \\
\text { (Two Doses) }\end{array}$ \\
\hline $\begin{array}{l}\text { AstraZeneca Plc., } \\
\text { University of } \\
\text { Oxford }\end{array}$ & $\begin{array}{l}\text { AZD1222 } \\
\text { ChAdO1nCov-19" }\end{array}$ & $\$ 10$ \\
\hline Pfizer, BioNTech & BNT162b2 & $\$ 39$ \\
\hline Sinovac Biotech & CoronaVac & $\$ 60$ \\
\hline $\begin{array}{l}\text { Serum Institute of } \\
\text { India, Novovax }\end{array}$ & Covovax & $\begin{array}{l}\text { In the process } \\
\text { of finalization }\end{array}$ \\
\hline $\begin{array}{l}\text { Moderna Inc., } \\
\text { National Institute } \\
\text { of Allergy and } \\
\text { Infectious mRNA-1273 } \\
\text { Diseases }\end{array}$ & mamaleya \\
\hline $\begin{array}{l}\text { Research Institute } \\
\text { Samaln V }\end{array}$ & $<\$ 20$ \\
\hline
\end{tabular}




\begin{tabular}{|l|l|l|}
\hline $\begin{array}{l}\text { China National } \\
\text { Pharmaceutical } \\
\text { Group } \\
\text { (Sinopharm) }\end{array}$ & New Crown Covid-19 & $\begin{array}{l}\text { Not more than } \\
\$ 149\end{array}$ \\
\hline
\end{tabular}

Corruptive activities in Covid-19 supports have been uplifting as it has been reminded about the jeopardy of corruption in delivering Covid-19 financial endowment for South Sudan. Even though several global institutions and county like the World Bank, the EU, the US, and the International Monetary Fund have underpinned roughly US\$300 million, numerous cases of corruption had appeared: the illegal market for Covid-19 tests has flourished as well; mark-up of the contracts kickbacks to the companies to regenerate vacant hospitals, and the discrimination by the government in deciding private sectors for producing hand sanitizer [18]. Meanwhile, a noticeable document from Ghana also states that more than US $\$ 2$ billion financial aspects given by certain institutions are also vulnerable to be misused [19].

Another quite severe problem is the problem of patient data. In some countries, there are suspicions that the data released by the Government is unreliable. Still referring to Transparency International, there is a tendency for countries to present data that is not under actual conditions. This data discrepancy has a terrible impact because this data is used for the procurement of medical goods, vaccines, and the procurement of large projects. In addition, data errors can reduce public awareness (as happened in Indonesia at the beginning of the pandemic, where the Government was very sure that Covid did not exist in Indonesia). On the other alternative, conversely, exaggerating data down lifts the degree of public trust in the government and will also impact public compliance with policies and laws issued by the Government to cope with COVID-19. Scientists believe that data showing insufficient data on COVID19 patients in several countries such as Mexico and the Philippines indicates a health crisis that does not match the facts on the ground.

Special Investigations Unit of South Africa detected corruption as the prominent reason of disadvantages, approximately US\$800 million in procuring contracts during the beginning of Covid-19. While in Uganda, a record by the Auditor General explained, Shs55.8 billion (almost US\$15.2 million) allocated for distributing Covid-19 relief goods was not included as a formal concern. In addition, the Zimbabwean anticorruption entity put roughly 40 boxes of Covid-19 test kits back after being illegally taken from a hospital in Bulawayo. Malawi also deals with the problem of managing the financial issue, approximately US $\$ 8$ million, intended for counteringCovid-19 [20]. South Africa's Special Investigation Unit (SIU) is investigating the corruption case of Zweli Mkhize, South Africa's Minister of Health, which is one of more than 4,000 coronavirus-related contracts suspiciously awarded since the start of the pandemic. SIU stets, 63 government officials were prosecuted, while 87 companies were also part of blacklists [21].

Zimbabwe's Minister of Health has been detained and accused of violating the rules after accepting bribes for appointing a company that sells medical goods to the Zimbabwean Government at inflated prices. Moyo awarded the contract worth 60 million US dollars to the company that bribed him without the approval of the Zimbabwean regulatory agency [22]. Meanwhile, Bolivian Health Minister Marcelo Navajas was detained by the police to buy ventilators at high prices. Procurement of this ventilator is for patients infected with COVID-19, most of whom have respiratory problems, so they are very dependent on ventilators. Navajas and his staff set a price per ventilator at 27 thousand US dollars, even though the price proposed by a Spanish manufacturing company was only 10 thousand dollars per unit. In other words, Navajas increased the price by more than $100 \%$ per ventilator. Bolivian president sacked Navajas to facilitate the investigation process [23].

Still related to ventilators, Rio Health Secretary Edmar Santos was arrested for corruption, one of which was the procurement of 1,000 ventilators. This megacorruption in Brazil amounted to 72.2 million dollars and impacted the increasing number of deaths due to not being provided with ventilators. Santos admitted that he was involved in various fraudulent schemes involving public tenders, as well as fraud cases still related to the COVID-19 pandemic [24]. The Secretary of State for Health (SES) also awarded a \$151 million contract to a non-profit organization called IABAS to set up seven hospitals to treat COVID019 patients in April. However, until the end of June, only two hospitals were open. One of the hospitals was even left unattended without treatment as cases in Rio declined. In this case, a local businessman Mario Peixoto was arrested for bribing the Government to secure various contracts related to public health, including a field hospital [24].

The former Minister of Social Affairs of the Republic of Indonesia, Juliari Batubara, was revealed to have committed acts of corruption to procure Social Assistance for communities affected by the Covid-19 pandemic in June 2020. The Corruption Eradication Commission suspected that Juliari had at least deducted IDR 10,000 from the package distributed to the Greater Jakarta area. Juliari is suspected of managing 1.6 million social assistance packages out of 1.9 million social assistance packages available. The KPK stated that at least Juliari got Rp32 billion from his corruption.

Moreover, Juliari also received bribes from two other suspects for the appointment of a company providing social assistance packages, namely Harry van Sidabukke and Ardian Iskandar Maddanatja, who bribed Rp. 1.28 billion and Rp. 1.95 billion, respectively. Andre Dedy Nainggolan, Head of the inactive KPK Investigative Task Force, stated that 
many things had not been revealed in handling corruption cases of Covid-19 social assistance. Andre said that the money received by Juliari at this time was not the whole that the KPK had successfully disclosed [25].

In addition to corruption cases that occurred in the central Government, there were also acts of corruption connected to the Covid-19 social assistance at the regional scale. The KPK investigates the allegations of corruption in procuring the Covid-19 social assistance in the West Bandung Regency by Regent Aa Umbara. He allegedly made a profit of Rp. 1 billion [26]. There is also corruption for the Covid-19 social assistance at the village level carried out by Askari, the Head of Sukowarno Village, Kec. Sukakarya, Kab. Musi Rawas, South Sumatra [27].

On March the $25^{\text {th }}$ in India, an incident happened at the Covid treatment center of a Mumbai mall; ten Covid-19 patients died. This mall does not have a complete occupancy certificate and fire audit. The leader of the Bharatiya Janata Party said that acts of corruption were the leading cause of this incident and asked the High Court to immediately investigate the matter [28]. In the first five-month of 2021, the corruption rate in India rose $19 \%$ from a year earlier. In January, the Anti-Corruption Bureau arrested 87 people; February 85 people; March 119 people; April 9 people; May 74 people. Local news said that the increase in corruption in India began to occur when the Government eased the lockdown [29].

In April this year, the Government of India has created a separate portal to deal with complaints associated with the coronavirus pandemic quickly. It has obtained more than 167,000 complaints relating to cases linked to the Covid-19. Of that, more than 150,000 have been tackled. Complaints have been collected on the website of the Department of State Apparatus Empowerment and Community Complaints. Corruption complaints sorted by the ministry including bribery, financial embezzlement, and harassment of government officials when tackling Covid-19 problems [30].

Bangladesh, India's neighbor, also faces more or less the same problem. The leader of the Bangladesh Labor Party, Rashed Khan Menon, said that the problem of corruption in Bangladesh is far more dangerous than the Covid-19 virus that is currently spreading. Menon said that people arriving at the district airport from many areas infected with the coronavirus were not adequately screened by the relevant officials. Referring to recent cases, he said that people easily enter Bangladesh from infected countries, including Singapore [31].

Executive Director of Transparency International Bangladesh, Iftekhar Uzzaman, said that his team found a deficit in good governance indicators in vaccine management activities. The existence of a third party who is given the space to benefit from the procurement of vaccines that has a business relationship with the Government violates the rules and laws. Iftekhar said the Government announced to provide vaccines to around 140 million people or $80 \%$ of the population, but so far, no specific strategy and pragmatic framework have been formulated to complete the challenging work. The risk of Covid-19 infection is increasing in the country due to the Government's insincerity in enforcing laws to force people to comply with its guidelines and partly from public apathy to maintain health safety rules. Iftekhar said corruption and irregularities in the health sector are still happening, as in the past [32].

In several other cases, such as in Pakistan, as explained before, the possibility of corruptive acts comes from the involvement of the private sector [17]. Later, a report from Ghana found that 12.4 billion cedis (over US\$2 billion) in funds came from the World Bank, IMF, Stabilization Fund of Ghana, Contingency Fund of the Stabilization Fund, Ghana Heritage Fund, Exim Bank of Ghana, and Trust Funds. Covid-19 risk from irregular procurement practices [19].

Iran has also found a tendency to deviate from the handling of the pandemic in the country. Corruption in Iran has hampered the Government's response to the handling of the coronavirus pandemic. People who have a 'network' try to control the distribution of Iran's protective masks and sanitary products. Iran largely needs masks, disinfectant, and alcohol while the availability of these things become a serious problem. According to one Iranian politician, the network that controls the price of face masks and sanitizers will not operate without influential authorities' help [33].

Based on the explanation above, the researcher compiles several forms of white-collar crimes corruption in various parts of the world because this research focuses on political corruption. In this case, the researcher categorizes it into only two, namely corporate crimes and crimes committed by government employees [12]:

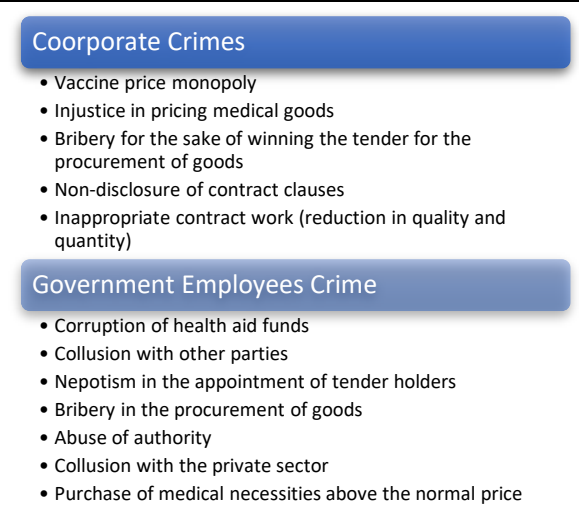

Fig. 2. Table 1. Forms of White-Collar Crime 


\section{B. White-Collar Crime Pattern in Handling the Covid-19 Pandemic}

Corruption is a crime anyone can commit, and in the context of this covid019 pandemic, it would be extensive if we were to discuss it in general terms. Therefore, this study is limited only to political corruption or corruption committed by a person because of his position in the Government. While explaining the pattern of white-collar crime, this research will only focus on the history of the perpetrator, the pattern of cooperation, and its impact on handling the COVID-19 pandemic in their respective countries.

\section{1) Perpetrator's background}

WCC actors, as stated by Sutherland, are people of respect and high social status in their work. Therefore, the factors of economic demand and poverty, and educational background become irrelevant in the WCC. The research team will take three actors for a complete study. This is because of the limited data and time that can be obtained.

The first suspected actor in the corruption of Covid19 social assistance in Indonesia is the former Minister of Social Affairs, Juliari Batubara. He has a very bright background, both in education and work. He started his political career as a member of the Indonesian House of Representatives from the Indonesian Democratic Party of Struggle in the first constituency of Central Java for two terms. While at the DPR RI, Juliari served in Commission VI, which handled industrial trade, investment, cooperatives, SMEs, BUMN and National Standardization [34]. Before entering politics, Batubara served as the head of several companies, namely PT Wiraswasta Gemilang Indonesia, PT. Arlinto Perkasa Buana, PT. Bwana Energy and PT Tridaya Mandiri. In addition, Juliari was also the Daily Chair of the Association of Indonesian Lubricants Producers (ASPELINDO) for the 2007-2014 period and was the Deputy Chair of the Permanent Committee on Access to Information on Business Opportunities in the Kadin MSME Sector in 2009-2010. Apart from having good work history, Batubara's educational background is also excellent. Coal is a graduate of Riverside City College in the United States and a graduate in administration from Chapman University in the United States.

The second is Marcelo Navas, the former Bolivian Minister of Health, who was arrested for purchasing ventilators at above-fair prices and other corruption charges. Navajas' educational background is in the medical field. Navajas is a surgeon who graduated from the Universidad Mayor de San Andres (UMSA) and got his speciality in Pulmonology and Thoracoplastic. Navajas is even a professor in that field. During his time as a doctor, Navajas served as the La Paz Departmental Surgery Society leader and the Bolivian International College of Surgeons. They were even one of 16 representatives of the International College of Surgeons worldwide and in other important positions related to his expertise as a thoracic surgeon [35].
The third is the Former Minister of Health and Child Care of Zimbabwe, prosecuted by the Courts of Zimbabwe [36]. Moyo was sued for awarding a contract amounting to US\$60 million without passing a transparent tender. Prior to being a politician, Moyo was a hospital administrator. Although in the future, many doubted his educational background. After being "the Executive Director of The Zimbabwe Kidney Fund Association's Renal Services", Moyo served as Chief Executive officer of Chitungwiza Central Hospital. His early career in politics was to run for the Nkayi regional representative in 2005 but failed. Then in 2018, it also lost its bid to enter the national parliament. Moyo was finally posted as Health and Child Protection Minister in 2018 under the Government of Emmerson Mnangagwa [37].

\section{2) Cooperation pattern}

In this case, the executive and the private sector are involved, who work together to harm the state's money with a considerable amount. This agreement states that a "fee" for each work must be deposited by partners (distributors) to the Ministry of Social Affairs through Santoso. The fee agreed between Santoso and AW is 10 thousand rupiahs per food package with the original value of 300 thousand rupiahs, as shown below. Coal is suspected of receiving bribes totaling 32.2 billion rupiahs. The details are 1.28 billion from entrepreneur Harry Sidabuke, 1.9 billion from Ardian IM, and 29.2 billion rupiahs from several companies providing necessities for COVID-19 social assistance [38]. In the first period of distribution of social assistance, 12 billion rupiahs of "circumcision" funds have been collected and given in cash to Coal worth 8.2 billion rupiahs. Furthermore, Coal's confidants, Eko and Shelvy, managed the money from the corruption to finance the minister's personal needs. Then in the second period of implementing the social assistance package, a fee of 8.8 billion rupiahs was collected [39].

Marcelo Navajas was dismissed from his post and is now waiting for a court decision due to his involvement in procuring ventilators at above-average prices. It all started when doctors treating COVID-19 patients stated that the ventilator purchased by the Bolivian Ministry of Health was not functioning correctly and did not meet Bolivian hospital emergency standards. The ventilator was just purchased through the Ministry of Health at a price four times the market price [24]. The 179 ventilators were allocated for a total price of US\$5 million using a third-party intermediary. The price of the ventilator purchased from the Spanish company GPA Innova is 27,683 US dollars per unit.

In contrast, the average price is around 7000 US dollars per unit [40]. The project is funded by the InterAmerican Development Bank (MID). In carrying out this action, Navajas colluded with several Bolivian Ministry of Health officials and BID officials, a total of four people. 
Obadiah Moyo follows a similar pattern to Navajas regarding his criminal charges. Moyo unilaterally and forced his subordinates to provide a project to procure civil-19 test kits and other medical items to the company Drax International LLC based in the United Arab Emirates [37]. The contract is related to the procurement of medical equipment, drugs worth 60 million US dollars. Included in the contract is the purchase of a medical mask for US\$25, of which the regular price is US\$3. Moyo also forced the treasurer to pay a bribe to release medical items at the airport. Zimbabwe's national pharmaceutical company, Natpharm, a non-profit and tasked with procuring and distributing all drugs and medical supplies to Zimbabwean public health institutions, is also implicated in this crime [41]. Before Moyo's arrest, four Natpharm officials were already in custody, along with Drax LLC's representative for Zimbabwe regarding the project with Drax LLC. Moyo's involvement, in this case, was an intervention and abuse of authority in project granting that was not carried out correctly. For an emergency reason, Moyo, together with Natpharm, accelerated the project process with Drax.

3) The Impact of WCC on the Handling of Covid19

The Covid-19 pandemic requires a swift response because the spread is so fast and massive. Governments are required to work fast, and most countries are not prepared to deal with it. So without considering the possibility of fraud, the policy is issued prematurely. In this section, the impact of the WCC on the handling of the pandemic from three cases, namely Indonesia, Bolivia, and Zimbabwe, will be explained.

In the case of social assistance corruption committed by Juliari Batubata, there was a deduction of aid initially worth 300 thousand rupiahs. The discount of 10 thousand rupiahs by Batubara reduces the value of the benefits of the assistance. In fact, according to ICW, the cut is not only 10 thousand rupiahs because 10 thousand is a request from Coal. The project implementers, of course, also want to take advantage, and it is estimated that the discount amount will reach 35 thousand rupiahs. Even though the target of the program is the poor, who are affected by the pandemic. After the Coal case was revealed, the Ministry of Finance and the Ministry of Social Affairs changed the distribution of aid to direct cash assistance. Funds disbursed by the Government through the Ministry of Social Affairs for the social protection of COVID-19 amounted to 230.21 trillion rupiahs. People who are pushed to close their businesses and cannot run their businesses due to large-scale social restrictions policies mainly depend on government social assistance for their livelihoods. Corruption perpetrated by Batubara has an impact on communities throughout JABODETABEK (Jakarta, Bogor, Depok, Tangerang, Bekasi). As a result of the corruption committed by Coal, the quality of social assistance received by the community has decreased in quality and quantity [42]. Communities who have been affected by the economy due to COVID-19 need this social assistance to survive. Meanwhile, for Coal, the result of the circumcision is only for his personal needs.

The Covid-19 pandemic requires a swift response because the spread is so fast and massive. Governments are required to work fast, and most countries are not prepared to deal with it. So without considering the possibility of fraud, the policy is issued prematurely. In this section, the impact of the WCC on the handling of the pandemic from three cases, namely Indonesia, Bolivia and Zimbabwe, will be explained.

Another impact of corruption by Batubara is the decline in public trust and satisfaction with the Joko Widodo administration. A certain survey done by the Indonesian Survey Institute (LSI) shows that public trust in Joko Widodo in handling COVID-19 has decreased since September 2020. Only 43\% of respondents believe Jokowi can handle COVID-19 (June 2021), down from February 2021, 55.6\%. Meanwhile, non-believers experienced an increase, namely $14.3 \%$ in February, increasing to $22.6 \%$ in June 2021.

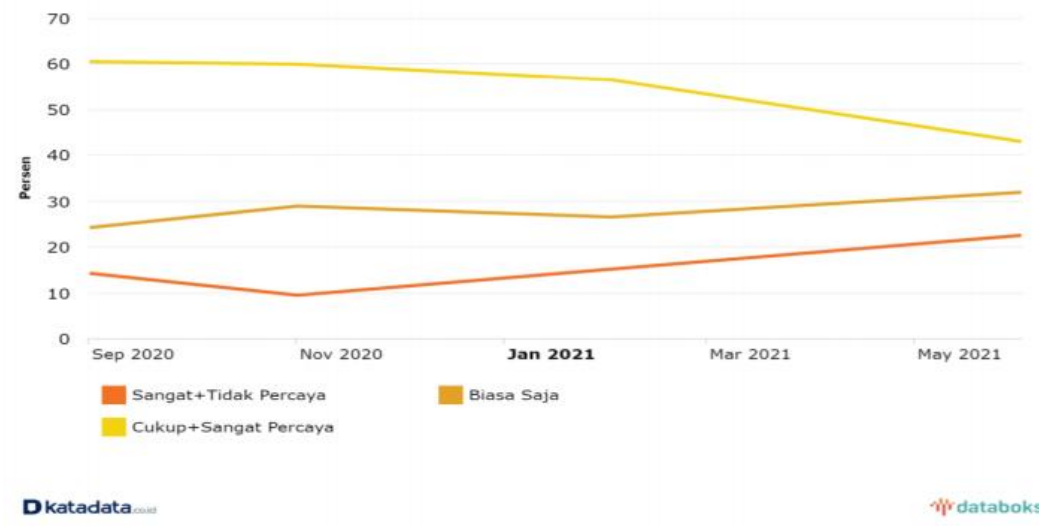

Fig. 3. Graphic 2. Level of Public Trust on The Government 
The decline in the level of public trust in the Government will have a broad impact. During this pandemic, the Government issued many policies and needed support from the community to implement all these policies. However, with the increasing public distrust of the Government, it is feared that this will reduce public compliance with policies issued by the Government. For example, a vaccine policy that requires full support from the community, based on the results of a Ministry of Health survey conducted by the University of Maryland, 33\% were hesitant to receive a vaccine, and $7.6 \%$ refused to be vaccinated at all [43]

Meanwhile, in the corruption case carried out by Marcelo Navajas, the patients and medical personnel who felt the impact were the patients. As a result of corruption committed by Navajas, the ventilators needed by Covid-19 patients did not work. At the same time, the ventilator is an essential tool for Covid-19 patients to survive. The 179 ventilators purchased at an above-fair price also lowered the level of confidence of the Bolivian people in the Government of President Jeanine Anez [44].

Obadiah Moyo's corruption in Zimbabwe is also related to the procurement of medical devices and medicines for COVID-19. Thus, the first to be affected by this crime are patients and medical personnel dealing with COVID-19 in Zimbabwe. Domestic conditions, which are also experiencing a terrible economic crisis, have further fueled public anger with the revelation of the Moyo corruption case (BBC, 2020). Zimbabwean medical workers have also taken to the streets demanding an increase in the welfare of those affected by the COVID-19, the severe economic crisis, and the collapse's end. Medical workers demand better wages (paid in US dollars, as the Zimbabwean currency is not accepted in transactions as its value declines). Personal protective equipment can protect them, as well as a better work environment [22]. Zimbabwe is in dire need of international assistance in order to remain economically viable. However, this corruption case will raise doubts about international institutions to channel aid.

\section{CONCLUSION}

The forms of political corruption crimes that occurred during the pandemic were divided into corporate crimes and crimes committed by government employees. Incorporate crime; the forms range from a monopoly on vaccine prices; Injustice in the pricing of medical goods; Bribery for the sake of winning the tender for the procurement of goods; Non-disclosure to contract clauses, or coercion to cover prices such as vaccines; and improper contract work (reduction in quality and quantity). Meanwhile, crimes committed by government employees are the corruption of health aid funds; Collusion with other parties; Nepotism in the appointment of tender holders; Bribery in the procurement of goods; Abuse of authority; Collusion with the private sector; Purchase of medical necessities above the regular price.

WCC criminals have impressive educational and occupational backgrounds. The criminals also came from the upper economic class and did not have a bad record against corruption. Their pattern of cooperation also involves many parties and other high-class networks such as corporate entrepreneurs, employees, and people from government institutions. Their crimes are more like profitable business transactions than organized crime. Even though the impact of their crimes is the wider community, starting from a decrease in the quality and quantity of social assistance, the quality of medical devices such as ventilators, and a decrease in government service standards related to the COVID-19 pandemic.

The Government is indeed forced to provide a fast response in dealing with the COVID-19 pandemic. However, on the other hand, monitoring of how policies are implemented also needs to be considered. Do not let the desire to respond quickly actually harm the people who want to be helped. There is a need to be strict supervision from several related entities: the Government, aid distribution agencies, and the community, to jointly maintain all governmental policies so that unscrupulous persons do not use them. The Government needs to be committed to anticorruption enforcement and take firm action against the WCC perpetrators. Aid agencies may also require a commitment to anti-corruption and transparency in aid delivery. Cooperation from across sectors will make the perpetrators of corruption and the WCC narrow in their space for committing crimes.

\section{REFERENCES}

[1] The World Health Organization. (2020, April 27). The World Health Organization. Retrieved from https://www.who.int/news/item/27-04-2020-who-timeline--covid-19

[2] The World Health Organization. (2021, February 28). WHO Coronavirus Disease (COVID-19) Dashboard. Retrieved from https://covid19.who.int

[3] Aljazeera. (2020, December 6). Indonesia: Batubara named suspect in COVID-19 corruption case. Retrieved from https://www.aljazeera.com/news/2020/12/6/indonesia-juliaribatubara- named-suspect-in-covid-19-graft-case

[4] VNExpress. (2020, April 23). Covid-19 fraud: Hanoi CDC officials inflated test kit prices by $\$ 200,000$. Retrieved from https://e.vnexpress.net/news/news/covid-19-fraud-hanoi-cdcofficials- inflated-test-kit-prices-by-200-000-4089233.htm

[5] Transparency International. (2020, September 24). COVID-19: Documented corruption and malfeasance cases. Retrieved from https://images.transparencycdn.org/images/COVID-19Documented- corruption-and-malfeasance-cases.pdf

[6] Transparency International. (2021, March 2). WHAT IS CORRUPTION? $\quad$ Retrieved from https://www.transparency.org/en/what-is-corruption

[7] Transparency International UK. (2021, April 22). CONCERN OVER CORRUPTION RED FLAGS IN 20\% OF UK'S PPE PROCUREMENT. Retrieved from https://www.transparency.org.uk/track-and-trace-uk-PPEprocurement-corruption-risk-VIP-lane 
[8] Andvig, J. C., Fjeldstad Inge Amundsen, O.-H., Sissener, T., $\&$ Søreide, T. (December, 2000). Research on Corruption A policy oriented survey. NORAD.

[9] Amundsen, I. (1999). Political Corruption: an Introduction to the Issues. Retrieved from https://www.cmi.no/publications/file/1040-politicalcorruption.pdf

[10] Payne, B. K. (2012). White-Collar Crime: a Text/Reader. Los Angeles: Sage.

[11] Sutherland, E. H. (1983). White Collar Crime. New York: Yale University. the United Nations Office on Drugs and Crime (UNODC). (2020, October 16). Good Practices Compendium on Combating Corruption in the Response to COVID-19. Retrieved https://www.unodc.org/pdf/corruption/G20_Compendium_C OVID-19_FINAL.pdf

[12] Sri Supatmi, M., \& Permata Sari, H. (2007). Dasar-Dasar Teori Sosial Kejahatan. Jakarta: PTIK Press.

[13] Mustofa, M. (2010). Kleptokrasi: Persekongkolan BirokratKorporat sebagai Pola White-Collar Crime di Indonesia. Jakarta: Kencana.

[14] Cornish, L. (2021, Juli 21). Interactive: Who's funding the COVID-19 response and what are the priorities? Retrieved Juli 27, 2021, from devex: https://www.devex.com/news/interactive-who-s-funding-thecovid-19-response-and-what-are-the-priorities-96833

[15] U4. (2021). Covid-19 and corruption. Retrieved from https://www.u4.no/topics/covid-19-and-corruption/basics

[16] Yap, D. (2021, Januari 18). Varying prices of Sinovac COVID19 vaccine raise alarm. Retrieved from Philippine Daily Inquirer: https://newsinfo.inquirer.net/1384867/sinovac-jabsvarying-prices-raise-alarm

[17] SciDev. (2021, April 6). COVID-19, lies and statistics. corruption and the pandemic. Retrieved from https://www.scidev.net/global/scidev-net-investigates/covid19-lies-and-statistics-corruption-and-the-pandemic/

[18] Mednick, S. (2021, April 7). Corruption claims spark new concerns about aid to South Sudan. Retrieved from Aljazeera: https://www.aljazeera.com/news/2021/4/7/corruption-claimsspark-new-concerns-about-aid-to-south-sudan

[19] AFP. (2021, Maret 24). South Africa: President Ramaphosa to face anti-corruption commission. Retrieved from Afrika News: https://www.africanews.com/2021/03/24/south-africapresident-ramaphosa-to-face-anti-corruption-commission/

[20] MODERNGHANA. (2021, April 16). COVID-19 pandemic increases corruption risks - Report. Retrieved from https://www.modernghana.com/news/1075255/covid-19pandemic-increases-corruption-risks.html

[21] Aljazeera. (2021, Juni 8). SA minister Zweli Mkhize put on leave over corruption allegations. Retrieved from https://www.aljazeera.com/news/2021/6/8/south-africahealth-minister-put-on-leave-over-corruption-allegation

[22] The Guardian. (2020, Juli 9). Zimbabwe health minister facing coronavirus corruption charge sacked. Retrieved Juli 27, 2021, from https://www.theguardian.com/globaldevelopment/2020/jul/09/zimbabwe-health-minister-facingcoronavirus-corruption-charge-sacked

[23] Aljazeera. (2020, Mei 23). Bolivia's health minister held for 'ventilator corruption'. Retrieved Juli 27, 2021, from https://www.aljazeera.com/news/2020/5/23/bolivias-healthminister-held-for-ventilator-corruption

[24] Reuters. (2020, September 25). The ventilators never came: How graft hampered Brazil's COVID-19 response. Retrieved from https://www.reuters.com/article/us-health-coronavirusbrazil-corruption/the-ventilators-never-came-how-grafthampered-brazils-covid-19-response-idUKKCN26G1EW

[25] TEMPO. (2021, Juli 28). Breaking News: Korupsi Bansos Covid, Juliari Batubara Dituntut 11 Tahun Penjara. Retrieved from https://nasional.tempo.co/read/1488251/breaking-newskorupsi-bansos-covid-juliari-batubara-dituntut-11-tahunpenjara

[26] tirto.id. (2021, Juli 7). KPK Periksa Kadinsos Soal Korupsi Bansos COVID-19 Bandung Barat. Retrieved from https://tirto.id/kpk-periksa-kadinsos-soal-korupsi-bansoscovid-19-bandung-barat-ghww

[27] tirto.id. (2021, April 12). Kades Korupsi Bansos Corona di Musi Rawas Dituntut 7 Tahun Penjara. Retrieved from https://tirto.id/kades-korupsi-bansos-corona-di-musi-rawasdituntut-7-tahun-penjara-gecT

[28] BJP blames corruption in BMC for fire at Mumbai hospital. (2021, Maret 26). Retrieved from https://www.telegraphindia.com/india/bjp-blames-corruptionin-bmc-for-fire-at-mumbai-hospital/cid/1810725

[29] Dalvi, V. (2021, Juni 13). Despite lockdown, no let up in corruption cases. Retrieved from https://mumbaimirror.indiatimes.com/mumbai/other/despitelockdown-no-let-up-in-corruptioncases/articleshow/83470159.cms

[30] Bhardwaj, D. (2020, Desember 7). PM seeks data on corruption complaints related to Covid-19. Retrieved from https://www.hindustantimes.com/india-news/centre-hasreceived-nearly-40-000-corruption-complaints-related-tocovid-19/story-tGEn6SrJpsgNL157Iozd4H.html

[31] Newagebd. (2020, Maret 7). Corruption turns more dangerous than coronavirus: Menon. Retrieved from https://www.newagebd.net/article/101497/corruption-turnsmore-dangerous-than-coronavirus-menon

[32] Opu, M. H. (2021, Juni 8). TIB: Third party's involvement behind vaccine crisis. Retrieved from https://www.dhakatribune.com/bangladesh/2021/06/08/tibthird-party-s-involvement-behind-vaccine-crisis

[33] MEE. (2020, MARET 5). Iranian press review: Corruption hinders Iran's response to coronavirus outbreak. Retrieved from https://www.middleeasteye.net/news/iranian-pressreview-corruption-hinders-irans-response-coronavirusoutbreak

[34] Kompas. (2019, Oktober 22). Juliari Batubara, Calon Menteri Pertama PDI-P yang Dipanggil Jokowi. Retrieved from https://nasional.kompas.com/read/2019/10/22/11215511/juliar i-batubara-calon-menteri-pertama-pdi-p-yang-dipanggiljokowi

[35] Ministro de Salud. (2021, April 8). Marcelo Navajas jura como nuevo Ministro de Salud Retrieved from https://www.minsalud.gob.bo/4037-marcelo-navajas-juracomo-nuevo-ministro-de-salud

[36] Africa Confidential. (2020, Agustus 6). Mnangagwa in search of enemies. Retrieved from https://www.africaconfidential.com/article/id/13044/Mnangagwa_in_search_of_ enemies

[37] The Herald. (2020, Juni 20). ZACC arrests health minister. Retrieved from https://www.herald.co.zw/zacc-arrests-healthminister/

[38] TEMPO. (2021, Maret 20). Kasus Korupsi Bansos, Juliari Batubara Disebut Mengelola 1,6 Juta Paket. Retrieved from https://nasional.tempo.co/read/1444170/kasus-korupsibansos-juliari-batubara-disebut-mengelola-16-juta-paket

[39] KPK. (2020, Desember 6). KPK Tahan Menteri Sosial Terkait Perkara Dugaan Suap Pengadaan Bansos Covid-19. Retrieved from https://www.kpk.go.id/id/berita/siaran-pers/1986-kpktahan-menteri-sosial-terkait-perkara-dugaan-suap-pengadaanbansos-covid-19

[40] Emergency Live. (2020, Mei 21). COVID 19 In Bolivia, Health Minister Marcelo Navajas Arrested Over The "Golden Ventilators" Scandal. Retrieved from https://www.emergencylive.com/news/covid-19-in-bolivia-health-minister-marcelonavajas-arrested-over-the-golden-ventilators-scandal/ 
[41] Gumbo, O. (2021). Mengatasi korupsi di Perusahaan Farmasi Nasional Zimbabwe - NatPharm. Diambil kembali dari ichi.pro: https://ichi.pro/id/mengatasi-korupsi-di-perusahaanfarmasi-nasional-zimbabwe-natpharm-14306907350440

[42] BBC. (2020, Desember 6). Mensos Juliari Batubara jadi tersangka korupsi bansos Covid-19, ancaman hukuman mati bakal menanti? Diambil kembali dari https://www.bbc.com/indonesia/indonesia-55204360
[43] Kemkes RI. (2021, Mei 12). 80,8\% Orang Indonesia Bersedia Menerima Vaksin COVID-19. Diambil kembali dari https://sehatnegeriku.kemkes.go.id/baca/berita-

utama/20210512/4437755/808-orang-indonesia-bersediamenerima-vaksin-covid-19/

[44] France24. (2020, Mei 20). Bolivian health minister held for suspected corruption. Retrieved from https://www.france24.com/en/20200520-bolivian-healthminister-held-for-suspected-corruption 